\title{
Characterization of Streptococcus lutetiensis isolated from clinical mastitis of dairy cows
}

\author{
Peng Chen, ${ }^{1}$ Yun Qiu, ${ }^{1}$ Gang Liu, ${ }^{1} \mathrm{Xi} \mathrm{Li},{ }^{1}$ Jia Cheng, ${ }^{1}$ Kai Liu, ${ }^{2}$ Weijie Qu, ${ }^{2} \odot$ Chunyan Zhu, ${ }^{3}$ \\ John P. Kastelic, ${ }^{4} \oplus$ Bo Han, ${ }^{1 *} \oplus$ and Jian Gao ${ }^{1 *} \odot$ \\ ${ }^{1}$ Department of Clinical Veterinary Medicine, College of Veterinary Medicine, China Agricultural University, Beijing 100193, China \\ ${ }^{2}$ College of Veterinary Medicine, Yunnan Agricultural University, Kunming 650201, China \\ ${ }^{3}$ Agri-Products Quality and Safety Testing Center of Shanghai, Shanghai 201708, China \\ ${ }^{4}$ Department of Production Animal Health, Faculty of Veterinary Medicine, University of Calgary, Calgary, AB, Canada, T2N 4N1
}

\begin{abstract}
Streptococcus lutetiensis, previously termed Streptococcus bovis type II/1, has rarely been associated with bovine mastitis. The objectives of this work were to characterize the molecular diversity, antimicrobial resistance profiles, virulence genes of Strep. lutetiensis (n $=37$ ) isolated from bovine clinical mastitis, as well as its pathogenic effects in a murine mastitis model. Genetic relationships of isolates were determined by random amplified polymorphic DNA (RAPD)-PCR, virulence genes were detected by PCR. Antimicrobial susceptibility testing was carried out by broth microdilution technique. The pathogenic effects of Strep. lutetiensis were studied with 2 infection models: bovine mammary epithelial cells cultured in vitro and murine mammary infection in vivo. Streptococcus lutetiensis isolates were clustered into 5 RAPD-types (A-E), with a dominant type A representing $84 \%$ of isolates. Eighteen (49\%), 16 (43\%), and 9 (24\%) isolates were resistant to ceftiofur, tetracycline, and erythromycin, respectively. Prevalence of multidrug resistance (resistant to $\geq 3$ classes of antimicrobials) was $24 \%$ (9/37). The most prevalent virulence genes were $b c a(100 \%)$, speG (100\%), hly (97\%), scpB (95\%), and ssa (95\%). There was no difference between isolates from mild and moderate cases of bovine mastitis in prevalence of virulence genes. Streptococcus lutetiensis rapidly adhered to and subsequently invaded ( 1 and $3 \mathrm{~h}$ after infection, respectively) bovine mammary epithelial cells, resulting in elevated lactate dehydrogenase release $(4 \mathrm{~h}$ after infection). Edema and hyperemia were observed in challenged mammary glands and bacteria were consistently isolated at 12,24 , and $48 \mathrm{~h}$ after infection. In addition,
\end{abstract}

Received February 11, 2020.

Accepted August 20, 2020.

*Corresponding authors: gaojian2016@cau.edu.cn and hanbo@cau .edu.cn numerous neutrophils migrated into gland alveoli and interstitium of infected mammary tissue. We concluded that Strep. lutetiensis had potential to spread within a dairy herd and good adaptive ability in bovine mammary cells or tissue, which are generally characteristics of a contagious mastitis pathogen.

Key words: bovine clinical mastitis, Streptococcus lutetiensis, random amplified polymorphic DNA (RAPD), antimicrobial resistance, pathogenicity

\section{INTRODUCTION}

Mastitis is one of the most common and costly diseases affecting dairy cattle worldwide, characterized by an inflammatory process in the mammary gland (Petrovski et al., 2006; Halasa et al., 2007). Streptococcus species, mainly Streptococcus dysgalactiae, Streptococcus agalactiae, and Streptococcus uberis, are the major pathogens causing bovine mastitis (Coffey et al., 2006; Zhang et al., 2018). Epidemiological studies in China reported that Streptococcus spp. are commonly detected in bulk tank milk and in milk samples collected from mastitic cows (Bi et al., 2016; Gao et al., 2017; Zhang et al., 2018).

Streptococcus bovis, classified as a nonenterococcal group D streptococcus, is routinely detected in human patients as part of the gut microbiota (Noble, 1978). Based on mannitol fermentation and $\beta$-glucuronidase activities, Strep. bovis was divided into 3 biotypes: (1) type I includes Streptococcus gallolyticus ssp. gallolyticus; (2) type II/1 includes Strep. lutetiensis and Streptococcus infantarius; and (3) type II/2 includes Strep. gallolyticus ssp. pasteurianus (Facklam, 2002; Poyart et al., 2002; Schlegel et al., 2003). In humans, Strep. lutetiensis was (1) detected in a patient with endocarditis (Chongprasertpon et al., 2019); (2) isolated from a child with diarrhea (Jin et al., 2013); and (3) present in blood samples from a patient with cholangitis (Almuzara et al., 2013). In animals, Piva et al. (2019) 
recently reported the isolation of Strep. lutetiensis from a cat with intestinal lymphoma.

In February 2019, a large number of group D streptococci were isolated from cows with clinical bovine mastitis in a commercial dairy farm in a northern province of China; these were ultimately identified as Strep. lutetiensis by $16 \mathrm{~S}$ rRNA sequencing analysis (Frank et al., 2008; Piva et al., 2019). Although this bacterium has only rarely been associated with bovine mastitis, the high isolation rate of Strep. lutetiensis on this dairy farm warranted further investigation. Therefore, objectives of this study were to determine the molecular diversity, antimicrobial resistance profile, distribution of virulence genes and pathogenic effects of Strep. lutetiensis isolated from cows with clinical mastitis (CM).

\section{MATERIALS AND METHODS}

\section{Statement of Ethics}

The present study was conducted in compliance with guidelines of the Beijing Municipality on the Review of Welfare and Ethics of Laboratory Animals, approved by the Beijing Municipality Administration Office of Laboratory Animals (BAOLA), and approved by the China Agricultural University Animal Ethics Committee (protocol CAU-AEC-2010-0603).

\section{Dairy Farm and Clinical Mastitis Data}

A commercial dairy farm located in northeast of China had on average 4,620 lactating Holstein-Friesian cows in February 2019 and 1-mo average bulk milk SCC of 185,000 cells/mL. Cows were fed a TMR and were housed in freestall facilities. Recycled manure solids (60\%) mixed with rice hull (40\%) was used as bedding. Lactating cows were milked thrice daily in a rotatory parlor. Iodine-based preparations were used both before and after milking ( 0.25 and $0.5 \%$ solutions, respectively). Ceftiofur (intramammary) and tetracycline (parenteral) were routinely employed as mastitis treatments.

The dairy farm surveilled CM by culturing milk samples from all cases in a microbiological laboratory. Briefly, milk samples were aseptically collected from individual quarters with $\mathrm{CM}$ and cultured following a bacteriological identification procedure used in the on-farm laboratory. Suspected Streptococcus spp. were identified as tiny gray colonies of gram-positive, catalase-negative cocci growing on blood agar and causing $\alpha$ - or $\beta$-hemolysis. For further identification, an Oxoid Streptococcal Grouping Kit (Oxoid, Hampshire, UK) was used to classify streptococcal groups in the on-farm laboratory.
In February 2019, 79 CM cases were recorded and categorized as mild (only abnormal milk), moderate (abnormal quarter, but no systemic clinical signs) or severe (signs of systemic illness) mastitis (Pinzón-Sánchez and Ruegg, 2011). Group D streptococci from pure culture were primarily identified in 37 samples (24 mild and 13 moderate $\mathrm{CM}$ cases). Other bacterial species were detected in 25 samples. No bacterial growth was observed in 16 samples, and 1 sample was considered contaminated due to presence of $>2$ species. Thereafter, samples were submitted to the Mastitis Diagnostic Laboratory of China Agricultural University (Beijing) for species-level identification of group D streptococci isolates.

\section{Bacterial Culture and Basic Tests}

In this experiment, $\beta$-SSA (Hopbio Co., Ltd., Qingdao, China) and sheep-blood agar were used to isolate and purify colony of the group D streptococci isolates, whereas brain heart infusion broth was used to subculture and proliferate bacteria. The biochemical reacting kit (Hangzhou Binhe Microorganism Reagent Co., Ltd., Hangzhou, China) was used for biochemical testing. Six reagents (glucose, esculin, sucrose, trehalose, sorbitol, and lactose) were fermented with isolates, in accordance with the manufacturer's instructions. Briefly, isolates were seeded in the tubes that were subsequently cultured in an incubator at $37^{\circ} \mathrm{C}$ for $18 \mathrm{~h}$, and the colors were compared with negative tubes. In the growth curve section, the medium had 5\% fetal bovine serum to ensure the growth of Strep. agalactiae, Strep. dysgalactiae, Strep. uberis and the group D streptococci isolates. Briefly, the mediums were diluted with distilled water, according to the manufacturer's instructions.

\section{S rRNA Sequencing Identification}

Bacterial DNA was extracted using a bacterial DNA extraction kit (Tiangen Biotech Co., Ltd., Beijing, China) according to the manufacturer's instructions. Species of group D streptococci isolates was determined by $16 \mathrm{~S}$ rRNA sequencing, where primer p27f (5'-AGAGTTTGATCCTGGCTCAG-3') and primer 1492r (5'-TACGGCTACCTTGTTACGACTT-3') were used to amplify a 1,466-bp product of the 16S rRNA gene, as described (Frank et al., 2008; Piva et al., 2019). The PCR cycling conditions included an initial denaturation step at $95^{\circ} \mathrm{C}$ for $5 \mathrm{~min}$, followed by 35 cycles at $95^{\circ} \mathrm{C}$ for $30 \mathrm{~s}, 55^{\circ} \mathrm{C}$ for $30 \mathrm{~s}$, and $74^{\circ} \mathrm{C}$ for $1.5 \mathrm{~min}$, with a final extension step at $74^{\circ} \mathrm{C}$ for $5 \mathrm{~min}$. The PCR products were subject to sequencing after verification on a $1 \%$ agarose gel. The $16 \mathrm{~S}$ rRNA sequences were compared with sequences deposited in the nucleotide 
database of the National Center for Biotechnology Information. Identification was deemed reliable if values for sequence similarities were $>99 \%$.

\section{SodA Sequencing Identification}

Bacterial genomic DNA collected using a bacteria DNA extraction kit (Tiangen Biotech Co., Ltd.) according to the manufacturer's instructions. The $\operatorname{sodA}$ degenerate primers d1 (5'-CCITAYICITAYGAYGCIYTIGARCC- $\left.3^{\prime}\right)$ and d2 (5'-ARRTARTAIGCARRTARTAIGCRTGYTCCCAIACRTC-3') were used to amplify the internal fragment of $\operatorname{sodA}$ (Poyart et al., 2002). The PCR cycling conditions included denaturation (3 min at $95^{\circ} \mathrm{C}$ ), followed by 30 cycles of amplification $\left(60 \mathrm{~s}\right.$ of annealing at $37^{\circ} \mathrm{C}, 60 \mathrm{~s}$ of elongation at $72^{\circ} \mathrm{C}$ and $30 \mathrm{~s}$ of denaturation at $95^{\circ} \mathrm{C}$; Poyart et al., 2002). Thereafter, PCR products were separated on a $1 \%$ agarose gel and verified by sequencing and comparisons to sequences deposited in the National Center for Biotechnology Information.

\section{Growth Curve of Strep. Iutetiensis}

The growth curves of Strep. lutetiensis, Strep. uberis, Strep. agalactiae, and Strep. dysgalactiae were assessed simultaneously. Three isolates from each Streptococcus species were used. These isolates were from different cows with CM from the same dairy farm. For each isolate, $3 \mathrm{~mL}$ of bacterial fluid was diluted in $60 \mathrm{~mL}$ brain heart infusion broth with $5 \%$ fetal bovine serum and well mixed. Thereafter, sterile tubes with $4 \mathrm{~mL}$ of aliquots were placed on a constant temperature shaker $\left(37^{\circ} \mathrm{C}, 220 \mathrm{rpm}\right)$. At $0,2,4,6,8,10,12,14,16,18$, $20,22,24,26$, and $28 \mathrm{~h}$ respectively, 1 tube per isolate was removed and optical density (OD) of bacterial suspension was determined at $600 \mathrm{~nm}$ in a UV spectrophotometer (Jingke Scientific Instrument Co., Ltd., Shanghai, China).

\section{RAPD Fingerprinting}

Molecular typing of Strep. lutetiensis isolates was performed using Primer 1254 (5'- CCGCAGCCAA-3'), as described (Khazandi et al., 2015). The reaction mixture $(25 \mu \mathrm{L})$ consisted of $12.5 \mu \mathrm{L}$ of TaqMix (TransGen Biotech Co., Ltd., Beijing, China), 1.5 $\mu \mathrm{L}$ of template DNA, $1 \mu \mathrm{L}$ of primer $(10 \mu M$; Sangon Biotech Co., Ltd., Shanghai, China) and $10 \mu \mathrm{L}$ of distilled water. The PCR program included an initial denaturation step at $94^{\circ} \mathrm{C}$ for 2 min, followed by 33 cycles of denaturation at $94^{\circ} \mathrm{C}$ for $30 \mathrm{~s}$, annealing at $33^{\circ} \mathrm{C}$ for $30 \mathrm{~s}$ and extension at $72^{\circ} \mathrm{C}$ for 2 min and a final extension at $72^{\circ} \mathrm{C}$ for $5 \mathrm{~min}$. The PCR products were separated by electrophoresis in 1.5\% (wt/vol) agarose gels (Bioweste, Nuaille, Spain) in $1 \times$ TAE buffer at $4 \mathrm{~V} / \mathrm{cm}$ for $3 \mathrm{~h}$ and the gel visualized with a UV transilluminator (Alpha Imager EC, Waltham, MA). The electrophoretic profiles obtained were normalized and analyzed using the software InfoQuest FP Software version 5.10 (BioRad Laboratories, Hercules, CA). Dendrograms were built using the unweighted pair group with arithmetic averages method, with use of the Dice coefficient $(\mathrm{Qu}$ et al., 2019). Optimization and position tolerance were set at 1.0 and $1.5 \%$, respectively. Isolates with $80 \%$ similarity or higher were assumed to belong to the same genotypic pattern (Duarte et al., 2004).

\section{Antimicrobial Resistance Determination}

Minimal inhibitory concentrations (MIC) of penicillin, vancomycin, imipenem, enrofloxacin, ceftiofur, erythromycin, and tetracycline (Coolaber Biotech Co., Ltd., Beijing, China) against Strep. lutetiensis isolates were determined by micro-broth dilution assays, following Clinical Laboratory and Standards Institute guidelines (CLSI, 2017). All antimicrobial agents were at concentrations ranging from 0.03 to $8 \mu \mathrm{g} / \mathrm{mL}$. Isolates were classified as resistant on the basis of clinical breakpoints described in CLSI (2017). Staphylococcus aureus ATCC 29213 and Escherichia coli ATCC 25922 were used as quality control strains. Antimicrobial resistance to a given antimicrobial was defined by combining intermediate and resistant categories into a single category. Multidrug resistance (MDR) was defined as resistance to $\geq 3$ classes of antimicrobial agents (Magiorakos et al., 2012).

\section{Virulence Gene Detection}

Potential virulence genes (scpB, hly, bca, bac, emm, smeZ, speA, spe $G$, and ssa) were detected by PCR, with primers and reference sources listed in Table 1 . Reaction mixtures $(25 \mu \mathrm{L})$ consisted of $12.5 \mu \mathrm{L}$ of TaqMix, $1 \mu \mathrm{L}$ of template DNA, $1 \mu \mathrm{L}$ of each primer, and $9.5 \mu \mathrm{L}$ of ultra-pure distilled water. Initial denaturation at $94^{\circ} \mathrm{C}$ for 2 min was followed by 34 cycles of amplification at $94^{\circ} \mathrm{C}$ for $30 \mathrm{~s}$, annealing at $58^{\circ} \mathrm{C}$ for $30 \mathrm{~s}$ (all primers), extension at $72^{\circ} \mathrm{C}$ for $2 \mathrm{~min}$, and a final extension step at $72^{\circ} \mathrm{C}$ for $5 \mathrm{~min}$. The PCR products were analyzed on a $2 \%$ agarose gel. For potential virulence genes, we confirmed that an isolate contained a target gene if the same size amplicon was observed as reported (Bidet et al., 2003; Masakado et al., 2003; Manning et al., 2006; Rato et al., 2011). 


\section{Cytotoxic Lactate Dehydrogenase Release Assay}

Based on random amplified polymorphic DNA (RAPD) profiles, Strep. lutetiensis isolate CM25 (RAPD-type A), CM16 (RAPD-type B) and CM33 (RAPD-type C) were selected for further pathogenicity studies, both in vitro and in vivo. Cytotoxic effects of Strep. lutetiensis on bovine mammary epithelial cells (bMEC) MAC-T (Jingma, Shanghai, China) were assessed using a lactate dehydrogenase (LDH) assay kit (Beyotime Biotechnology, Beijing, China). Cells were cultured at $37^{\circ} \mathrm{C}$ with $5 \% \mathrm{CO}_{2}$ in 96 well plates (Corning Inc., Corning, NY) and challenged with the selected isolates, at a multiplicity of infection (MOI, ratio of Strep. lutetiensis to cells) of 5:1 for $0.5,1,2,4$, and $8 \mathrm{~h}$. Noninfected cells were similarly incubated as a control. After incubation, $200 \mu \mathrm{L}$ of supernatants from each well was collected and transferred to centrifuge tubes and centrifuged $\left(8,000 \times g\right.$ for $5 \mathrm{~min}$ at $\left.4^{\circ} \mathrm{C}\right)$. Then, $120 \mu \mathrm{L}$ of supernatant was transferred to a new 96well polystyrene plate, with $60 \mu \mathrm{L}$ of reaction mixture added to each well, followed by incubation on a rotary shaker $(150 \mathrm{rpm})$ at room temperature in the dark for 30 min. Absorbance was read at $490 \mathrm{~nm}$ (680 Multipurpose Microplate Reader, Bio-Rad Laboratories).

\section{Adhesion and Invasion Assay}

Bacterial adhesion and invasion of CM16, CM25 and CM33 isolates were determined as described (Chen et al., 2017; Liu et al., 2019). Briefly, bMEC cultured in 6-well plates (Corning Inc.) and infected with Strep. lutetiensis (CM16, CM25, and CM33) at an MOI of 50:1 for $30 \mathrm{~min}$ and for 1, 2, and $3 \mathrm{~h}$. Following incu- bation, cells were washed with sterile PBS ( $\mathrm{pH} 7.4$ ) in triplicate and treated with $100 \mu \mathrm{g} / \mathrm{mL}$ gentamicin (Sigma-Aldrich, St. Louis, MO) for $2 \mathrm{~h}$ to kill extracellular Strep. lutetiensis. Supernatants were collected and plated on SBA to verify killing had occurred. Infected cells without antibiotic treatment were used as a control group. Cells were washed with sterile PBS in triplicate and lysed with $0.5 \%$ (vol/vol) triton X-100. Cell lysates were diluted 10-fold, cultured on SBA and incubated at $37^{\circ} \mathrm{C}$ for $24 \mathrm{~h}$ to count colony-forming units. Invasion rate of adhered bacteria was expressed as

Invasion rate of bacteria $=$

Lysate of infected cells with antibiotic treatment $(\mathrm{cfu} / \mathrm{mL})$

Cell lysates and treated bacterial supernatants in control group (cfu/mL) $\times 100$.

To assess adhesive capacity of Strep. lutetiensis to bMEC, an adhesion assay was performed as described (Liu et al., 2019) with slight modifications. The bMEC cultured in 6-well plates (Corning Inc.) for $3 \mathrm{~d}$ in antibiotic-free medium to reach confluency were infected with Strep. lutetiensis (MOI 50:1) for $30 \mathrm{~min}$ and for 1, 2 and $3 \mathrm{~h}$ at $37^{\circ} \mathrm{C}$ with $5 \% \mathrm{CO}_{2}$. After incubation, cells were washed in duplicate with sterile PBS ( $\mathrm{pH}$ 7.4) to remove nonassociated bacteria. Cells were lysed by adding $1 \mathrm{~mL}$ PBS and $1 \mathrm{~mL} \mathrm{1 \%}$ triton X-100 (0.5\% vol/vol) to release associated bacteria (adhering and invasive). In the control group, both bacterial suspensions $(1 \mathrm{~mL})$ and cells were also treated with $1 \mathrm{~mL}$ triton X-100. Cell lysates and treated bacterial supernatants were diluted 10 -fold, cultured on SBA and incubated at $37^{\circ} \mathrm{C}$ for 24 $\mathrm{h}$ and colony-forming units enumerated. The adhesion rate was determined as follows:

Table 1. The PCR primers used for detecting virulence genes in Streptococcus lutetiensis isolates

\begin{tabular}{|c|c|c|c|c|}
\hline Gene & Sequence $^{1}\left(5^{\prime}\right.$ to $\left.3^{\prime}\right)$ & Functional protein & $\begin{array}{l}\text { Amplicon } \\
\text { size (bp) }\end{array}$ & Reference \\
\hline $\operatorname{scp} B$ & $\begin{array}{l}\text { F: AGCCATATGCTGCGATCTCT } \\
\text { R: GGGTTGAACCAAGTGTGCTT }\end{array}$ & C5a peptidase & 198 & Bidet et al., 2003 \\
\hline$h l y$ & $\begin{array}{l}\text { F: TCCATTTAAAGCCCTTGGTG } \\
\text { R: GGCGCCAGTATAAGCAACAT }\end{array}$ & Hemolysin & 199 & Bidet et al., 2003 \\
\hline$b c a$ & $\begin{array}{l}\text { F: TAACAGTTATGATACTTCACAGAC } \\
\text { R: ACGACTTTCTTCCGTCCACTTAGG }\end{array}$ & $\alpha \mathrm{C}$ protein & 535 & Manning et al., 2006 \\
\hline$b a c$ & $\begin{array}{l}\text { F: CTATTTTTGATATTGACAATGCAA } \\
\text { R: GTCGTTACTTCCTTGAGATGTAAC }\end{array}$ & $\beta \mathrm{C}$ protein & 592 & Manning et al., 2006 \\
\hline $\mathrm{emm}$ & $\begin{array}{l}\text { F: TATTCGCTTAGAAAATTAA } \\
\text { R: GCAAGTTCTTCAGCTTGTTT }\end{array}$ & Antiphagocytic M protein & Variable & Rato et al., 2011 \\
\hline smeZ & $\begin{array}{l}\text { F: CTTCAATATTCATTGCAATAATTTC } \\
\text { R: TGTAACTGTTGTTTTGTTAGTTGAT }\end{array}$ & Mitogenic exotoxin Z & 400 & Rato et al., 2011 \\
\hline speA & $\begin{array}{l}\text { F: ATGGAAAACAATAAAAAAGTATTG } \\
\text { R: TTACTTGGTTGTTAGGTAGACTTC }\end{array}$ & Pyrogenic exotoxin A & 755 & Masakado et al., 2003 \\
\hline spe $G$ & $\begin{array}{l}\text { F: TGTATCTTTAGGGATTACTGATCAG } \\
\text { R: CTCGACCTAAAAGCTTATCATCCTT }\end{array}$ & Pyrogenic exotoxin $\mathrm{G}$ & 389 & Rato et al., 2011 \\
\hline$s s a$ & $\begin{array}{l}\text { F: TCCACAGGTCAGCTTTTACAG } \\
\text { R: TGATCAAATATTGCTCCAGGTG }\end{array}$ & Streptococcal superantigen & 502 & Masakado et al., 2003 \\
\hline
\end{tabular}

${ }^{1} \mathrm{~F}=$ forward; $\mathrm{R}=$ reverse. 
Adhesion rate of bacteria $=$

Cell lysate of infected group $(\mathrm{cfu} / \mathrm{mL})$

$\overline{\text { Cell lysates and treated bacterial supernatants in control group (cfu/mL) }}$ $\times 100-$ Invasion rate.

Invasion and adhesion assays were repeated 3 times and each experiment was performed in triplicate.

\section{Murine Mammary Infection Model for Strep. Iutetiensis}

Female 6-8-wk-old specific-pathogen-free BALB/c mice (Merial-Vital Laboratory Animal Technology, Beijing, China) were used to determine the pathogenic role of Strep. lutetiensis during intramammary infection, as described (Liu et al., 2019). Pregnant (20 d of gestation) mice were kept in germfree isolators and fed ad libitum in a controlled environment with light and dark cycles (12 $\mathrm{h}$ light and $12 \mathrm{~h}$ darkness). On the third day after parturition, mice were anesthetized with intramuscular injection of $50 \mathrm{mg} / \mathrm{kg}$ Zoletil 50 (Virbac, Carros, France). Ducts of the fourth pair of mammary glands were exposed by cutting the teat tip and $100 \mu \mathrm{L}$ of bacterial suspension $\left(10^{6} \mathrm{cfu}\right)$ was slowly injected using a gauge blunted needle (Hamilton Company, Reno, $\mathrm{NV}$ ). Four groups ( $\mathrm{n}=20$ per group) of mice were allocated with 3 challenge groups (Strep. lutetiensis CM16, CM25, and CM33, respectively) and 1 negative control group (sterile PBS). The pups were removed 2 $\mathrm{h}$ before intramammary inoculation. The sedated mice were euthanized by cervical dislocation and dissected. The skin was fixed by pins before photographing the mammary glands. Bacterial burden in mammary glands at 12,24 , and $48 \mathrm{~h}$ after challenge $(5$ mice for each time point) was measured as described (Liu et al., 2019). Briefly, mammary gland tissue (0.1 g) was separated into a sterile tube under a germfree environment. After grinding, $50 \mu \mathrm{L}$ supernatant was spread on sheep-blood plates (multiple dilutions). Numbers of viable colonies were expressed as colony-forming units per gram. Mammary gland tissue was fixed in 5\% of paraformaldehyde, embedded, sectioned and stained with hematoxylin-eosin. Histological evaluation was performed to assess tissue necrosis, polymorphonuclear neutrophilic granulocyte inflammation (i.e., neutrophilic inflammation) and lymphocytic inflammation, as described (Liu et al., 2019).

\section{Statistical Analyses}

SPSS 20.0 (SPSS Inc., Chicago, IL) was used to analyze the data. One-way ANOVA was used to compare $\mathrm{LDH}$ release, invasion and adhesion rates between treatment groups, with Duncan's tests used to locate differences. Chi-squared tests were used to study associations between virulence genes and mastitis severity (milk and moderate). Differences were considered significant if $P<0.05$.

\section{RESULTS}

\section{Morphological Characteristics of Strep. Iutetiensis}

Streptococcus lutetiensis formed round, smooth colonies $\sim 1 \mathrm{~mm}$ in diameter on trypticase soy agar with $5 \%$ sheep blood after incubation at $37^{\circ} \mathrm{C}$ for $24 \mathrm{~h}$ (Figure 1A). The colonies were light-gray and needle tip-shape, with $\alpha$-hemolysis (Figure 1A). They appeared as short chains of gram-positive cells (Figure 1B). All isolates fermented esculin, sucrose, trehalose, and sorbitol.

\section{Growth Ability of Strep. Iutetiensis}

Growth curves of Strep. lutetiensis, Strep. uberis, Strep. dysgalactiae, and Strep. agalactiae isolates cultured in brain heart infusion broth are shown (Figure 1C). For Strep. lutetiensis, the bacterial-growth curve consisted of a lag phase $(\sim 2 \mathrm{~h})$, a log phase $(\sim 6 \mathrm{~h})$ and ultimately a stationary phase. Based on subjective observations, the growth curve of Strep. lutetiensis had a shortened lag phase. Additionally, the $\mathrm{OD}_{600 \mathrm{~nm}}$ value of Strep. lutetiensis isolates reached as high as $\sim 0.8$, whereas it was up to $\sim 0.6$ for Strep. uberis, $\sim 0.8$ for Strep. dysgalactiae and $\sim 0.5$ for Strep. agalactiae isolates.

\section{Molecular Diversity of Strep. Iutetiensis}

The RAPD profiles of Strep. lutetiensis resulted in DNA amplification fragments ranged in size from 2,000 to 7,000 base pairs. Genomic variability in all isolates was determined using RAPD-PCR analysis (Figure $2)$. The 37 isolates were clustered into 5 RAPD-types (A-E), with the prevalent RAPD-type A representing $84 \%$ of isolates $(31 / 37)$. In addition, RAPD-type $B$ and $\mathrm{D}$ contained 2 isolates each.

\section{Antimicrobial Resistance Profiles of Strep. Iutetiensis}

Resistance of Strep. lutetiensis to enrofloxacin was most prevalent $(63 \%)$, followed by ceftiofur $(49 \%)$, tetracycline $(43 \%)$, erythromycin $(24 \%)$, penicillin $(9 \%)$, and imipenem (8\%; Table 2). However, all isolates were susceptible to vancomycin. In total, $24 \%(9 / 37)$ of isolates were resistant to $\geq 3$ classes of antimicrobial agents and therefore defined as MDR. From a total 

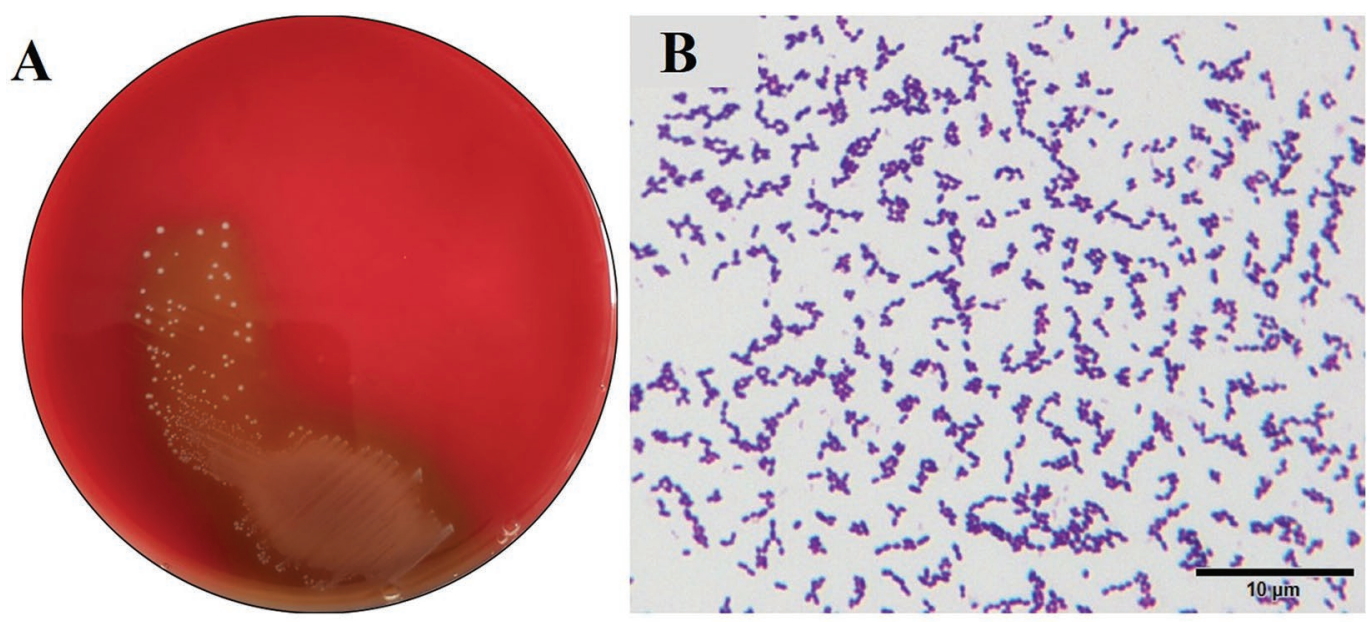

C

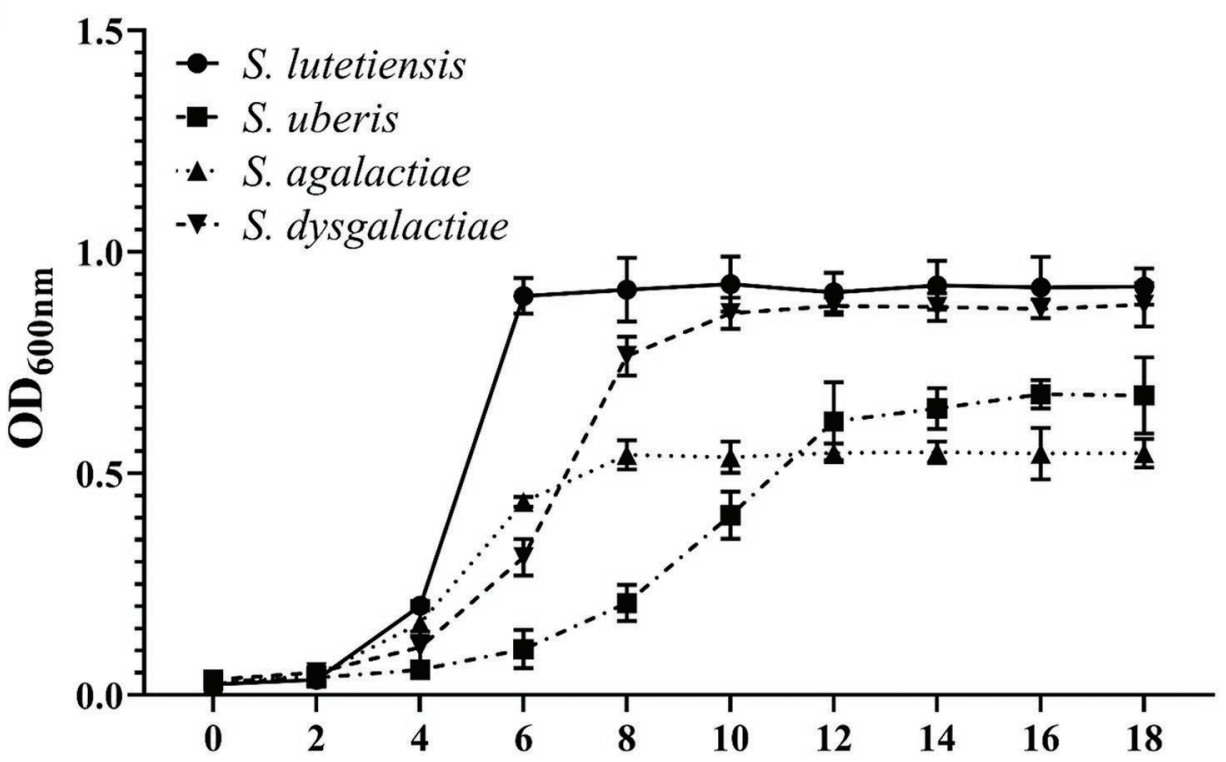

Figure 1. Morphological characteristics and growth curves of Streptococcus lutetiensis. (A) Needlelike colonies with $\alpha$-hemolysis were observed on trypticase soy agar with $5 \%$ sheep blood; (B) short-chain gram-positive cocci were observed under an optical microscope (1,000×); and (C) growth curves of Strep. lutetiensis, Streptococcus uberis, Streptococcus agalactiae, and Streptococcus dysgalactiae isolates. Data are mean $\pm \mathrm{SD}$ of $\mathrm{OD}_{600} \mathrm{~nm}$ values of 3 isolates from each Streptococcus species. $\mathrm{OD}_{600} \mathrm{~nm}=$ optical density at a wavelength of $600 \mathrm{~nm}$.

of 9 MDR isolates, 1 and 8 were resistant to 3 and 4 antimicrobial classes, respectively.

\section{Distribution of Virulence Genes in Strep. Iutetiensis}

There were $36(95 \%)$ Strep. lutetiensis isolates with the hly gene (encoding hemolysin) and 35 (97\%) with the $s c p B$ gene (encoding C5a peptidase; Table 3). However, the emm gene encoding antiphagocytic M protein was not detected in any isolate. For genes encoding $\mathrm{C}$ protein, $b c a$ (encoding a $\mathrm{C}$ protein) was detected in $100 \%$ of isolates; however, bac (encoding $\beta \mathrm{C}$ protein) was not detected. Among genes encoding superantigens (SAgs), the speG gene (encoding pyrogenic exotoxin G) was detected in all Strep. lutetiensis isolates. The ssa gene (encoding streptococcal SAg) and the smeZ gene which encodes mitogenic exotoxin $\mathrm{Z}$ were detected in 95 and $57 \%$ of isolates, respectively. In contrast, speA (encoding pyrogenic exotoxin A) was not detected in any isolate. There was no difference in prevalence of virulence genes between isolates from mild versus moderate CM cases $(n=24$ and $n=13$, respectively).

\section{Pathogenic Effects of Strep. Iutetiensis on bMEC}

At $0.5,1$, and $2 \mathrm{~h}$ after infection, there was no difference between control and infected groups for LDH release (Figure 3A). However, all 3 Strep. lutetiensis 


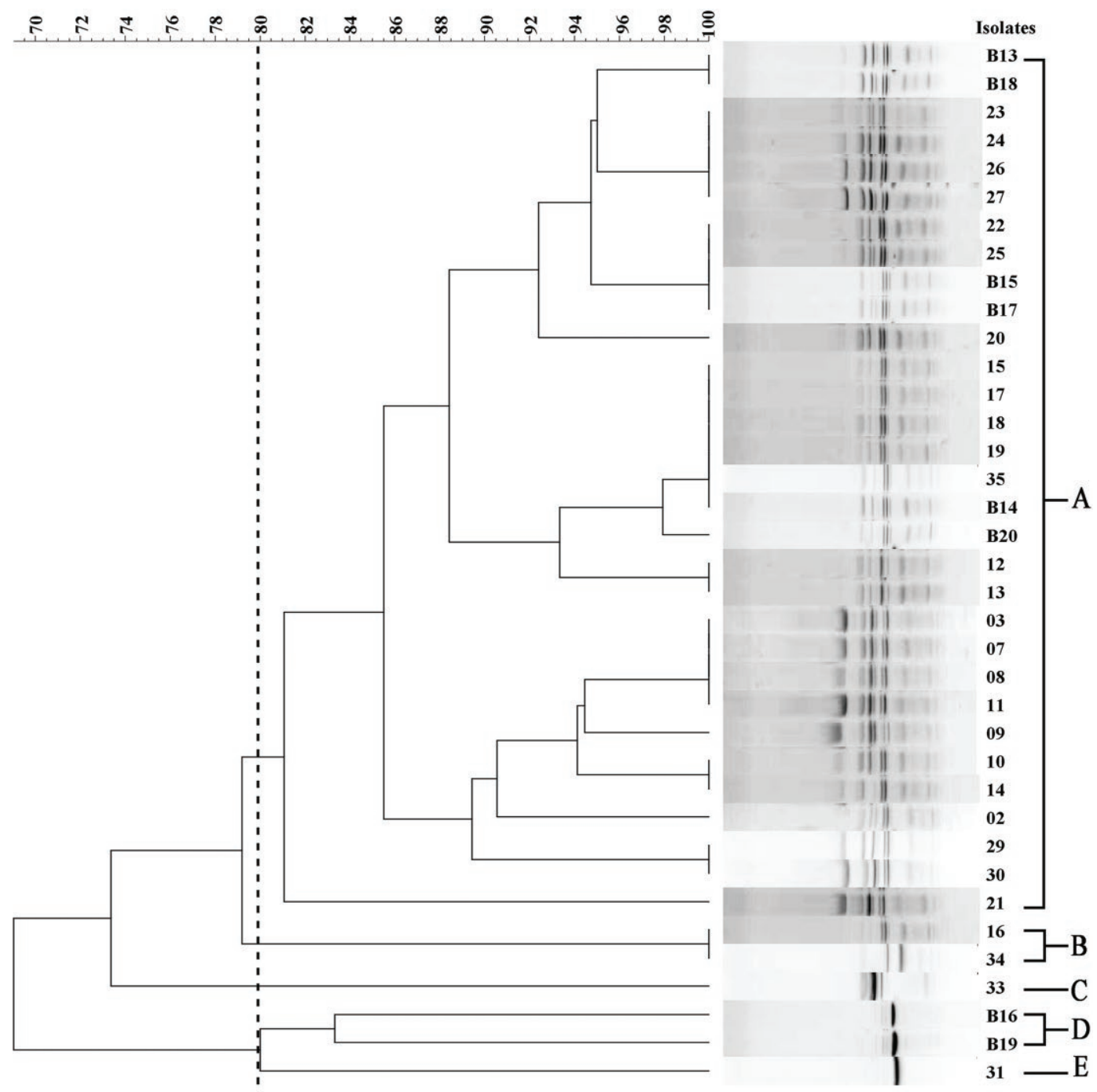

Figure 2. Dendrogram derived from random amplified polymorphic DNA (RAPD) of Streptococcus lutetiensis. An $80 \%$ similarity was chosen as a discriminating threshold to define homogeneous clusters.

Table 2. Number of isolates at each MIC value of antimicrobial agents against Streptococcus lutetiensis isolates ${ }^{1}$

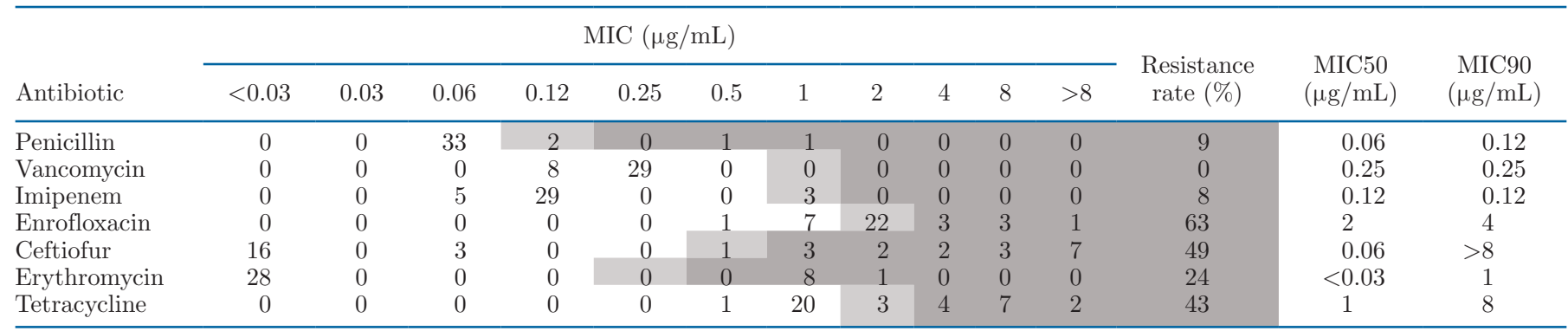

${ }^{1}$ The breakpoints from human $\beta$-hemolytic streptococci were used (CLSI, 2017): penicillin $\geq 0.12 \mu \mathrm{g} / \mathrm{mL}$; vancomycin $\geq 1 \mu \mathrm{g} / \mathrm{mL} ; \mathrm{imipenem} \geq 1$ $\mu \mathrm{g} / \mathrm{mL}$; enrofloxacin $\geq 2 \mu \mathrm{g} / \mathrm{mL}$; ceftiofur $\geq 0.5 \mu \mathrm{g} / \mathrm{mL}$; erythromycin $\geq 0.25 \mu \mathrm{g} / \mathrm{mL}$; and tetracycline $\geq 2 \mu \mathrm{g} / \mathrm{mL}$. MIC M0 $_{0}$ is the middle value and $\mathrm{MIC}_{90}$ is the $90 \%$ value of these isolates after sorting antimicrobial data into "orderly array" (Hamilton-Miller, 1991). Unshaded cells indicate that the MIC value was less than the breakpoint, light gray shading indicates the MIC breakpoint, and dark gray shading indicates MIC values exceeding the breakpoint. 
Table 3. Prevalence (no.; \% in parentheses) of virulence genes in Streptococcus lutetiensis isolates from mild and moderate clinical mastitis cases

\begin{tabular}{lcccc}
\hline \multicolumn{4}{c}{ Clinical mastitis cases } & \\
\cline { 2 - 4 } $\begin{array}{l}\text { Virulence } \\
\text { gene }\end{array}$ & $\begin{array}{c}\text { Mild } \\
(\mathrm{n}=24)\end{array}$ & $\begin{array}{l}\text { Moderate } \\
(\mathrm{n}=13)\end{array}$ & Total & $P_{\text {-value }}$ \\
\hline scpB & $22(92)$ & $13(100)$ & $35(95)$ & 0.28 \\
hly & $24(100)$ & $12(90)$ & $36(97)$ & 0.17 \\
bca & $24(100)$ & $13(100)$ & $37(100)$ & - \\
bac & $0(0)$ & $0(0)$ & $0(0)$ & - \\
emm & $0(0)$ & $0(0)$ & $0(0)$ & - \\
smeZ & $14(58)$ & $7(54)$ & $21(57)$ & 0.79 \\
speA & $0(0)$ & $0(0)$ & $0(0)$ & - \\
speG & $24(100)$ & $13(100)$ & $37(100)$ & - \\
ssa & $22(92)$ & $13(100)$ & $35(95)$ & 0.28 \\
\hline
\end{tabular}

${ }^{1}$ Difference in prevalence of a virulence gene between isolates from mild versus moderate mastitis cases.

increased LDH release from cells at $4 \mathrm{~h}$ after infection, peaking at $8 \mathrm{~h}$ after infection $(P<0.05)$. The 3 isolates rapidly ( $1 \mathrm{~h}$ after infection) adhered to bMEC and reached to a peak (49.5\% on average) at $4 \mathrm{~h}$ after infection (Figure 3B). In addition, Strep. lutetiensis invaded into bMEC quickly at $3 \mathrm{~h}$ after infection and reached a peak ( $8.9 \%$ on average) at $4 \mathrm{~h}$ after infection (Figure $3 \mathrm{C})$. There was no significant difference between infection groups for LDH release or adhering/invading rates.

\section{Inflammation of Murine Mammary Gland Infected by Strep. Iutetiensis}

Systemic clinical signs, such as exacerbated dyspnea, anorexia, and sluggishness, were not observed in mice challenged by Strep. lutetiensis. However, 27\% (16 of 60 ) of mice had swollen mammary glands (data not shown) during the 48-h experiment. Edema and hyperemia were evident in murine mammary glands at $24 \mathrm{~h}$ after infection with Strep. lutetiensis, with more profound pathological changes over time ( $48 \mathrm{~h}$ after infection; Figure 4A). Bacteria were isolated from mammary glands of mice challenged with Strep. lutetiensis, whereas no bacteria were isolated from the noninfected control group. The bacterial load (mean value) was 2.5 $\times 10^{7} \mathrm{cfu} / \mathrm{g}$ at $12 \mathrm{~h}$ after infection, but rapidly increased to $9.6 \times 10^{7} \mathrm{cfu} / \mathrm{g}$ at $48 \mathrm{~h}$ after infection (Figure $4 \mathrm{~B}$ ). Histological characteristics of the Strep. lutetiensis infected mammary glands were assessed (Figure 5). Infiltrating inflammatory cells (mainly neutrophils) were observed in the gland alveoli and interstitium of the infected mammary gland at $12 \mathrm{~h}$ after infection. Some mammary epithelial cells were present in the lumen of mammary alveoli, due to degradation and necrosis. There was no evidence of inflammation in mice from the control group (uninfected).

\section{DISCUSSION}

This was apparently the first report of Strep. lutetiensis associated with bovine CM. This bacterium belongs to the Strep. bovis group and was previously denoted as Strep. bovis biotype II/1 before a change in taxonomic nomenclature (Tripodi et al., 2005). Perhaps some Strep. bovis isolated from cows with mastitis a long time ago were actually Strep. lutetiensis (Garvie and Bramley, 1979). Although Strep. lutetiensis is not a common cause of mastitis compared with Strep. uberis, Strep. dysgalactiae, and Strep. agalactiae (Gao et al., 2017; Ruegg, 2017), the high isolation rate on this commercial dairy farm were the impetus to characterize this pathogenic bacterium. Data on genetic diversity, antimicrobial resistance and virulence profile of Strep. lutetiensis can inform evidence-based treatment and control programs.

With $80 \%$ similarity threshold, 1 predominant RAPDtype representing $84 \%$ of isolates was identified in the current study, indicating potential contagious transmission or multiple exposures to a common source. Among Streptococcus species causing mastitis, Strep. agalactiae is a typical contagious pathogen, mainly spread during milking (Ruegg, 2017), whereas Strep. uberis and Strep. dysgalactiae are usually considered opportunistic environmental pathogens with limited ability to spread between cows (Lundberg et al., 2014; Wente et al., 2019).

Antimicrobial resistance is one of the biggest threats to global health, food security and development (WHO, 2015). In the present study, a considerable number of isolates were resistant to ceftiofur and tetracycline, which were commonly used to treat CM on this dairy farm. However, results of in vitro susceptibility tests should not be used as the primary guide for treatment success (Constable and Morin, 2003; Apparao et al., 2009). Streptococcus lutetiensis had limited resistance to penicillin, the antimicrobial of choice to treat streptococcal mastitis (Pyörälä, 2009). One quarter of isolates were identified as MDR, suggesting that antimicrobials should be prudently used to avoid rapid development of antimicrobial resistance in Strep. lutetiensis. Similar to this study, an MDR Strep. lutetiensis recently isolated from a fecal sample of a cat with intestinal lymphoma was resistant to clindamycin, enrofloxacin, erythromycin, imipenem, marbofloxacin, and tetracycline (Piva et al., 2019). A nationwide survey from China reported that proportion of MDR isolates in Streptococcus species from CM was 21\% (Cheng et al., 2019), similar to our report.

Proportions of mild and moderate mastitis in the present study were consistent with a previous report (Verbeke et al., 2014). It has been reported that virulence genes may enhance the pathogenicity of bacteria 
(Casadevall and Pirofski, 1999). For Streptococcus isolates, C5a peptidase coded by $\operatorname{scp} B$ gene, determines the fibronectin-binding activity and increases immune escape ability (Beckmann et al., 2002). The high prevalence of the $\operatorname{spB}$ gene in this study highlighted the potential of Strep. lutetiensis to escape the mammary immune system of cows. The bac gene, which is intrinsic for streptococci to enhance adhesion and colonization (Baron et al., 2004) was also detected in 100\% of isolates. All of those characteristics could enhance the potential virulence of Strep. lutetiensis to cause mastitis. Streptococcal SAgs, a family of highly potent mitogens that share the ability to trigger stimulation of $\mathrm{T}$ lymphocytes and release of pro-inflammatory cytokines, have been widely involved in a range of human diseases in (Proft and Fraser, 2016). Of the genes encoding SAgs, speG and ssa were more prevalent in Strep. lutetiensis than in Strep. pyogenes isolated from human infections (Friaes et al., 2013), whereas detection rate of the smeZ gene was lower in the present study. There was no difference in distribution of virulence genes between isolates from mild and moderate CM cases, indicating that presumably some other factors were associated with severity of CM caused by Strep. lutetiensis.

Pathogenic effects of Strep. lutetiensis were assessed using both in vitro and in vivo infection models. Three
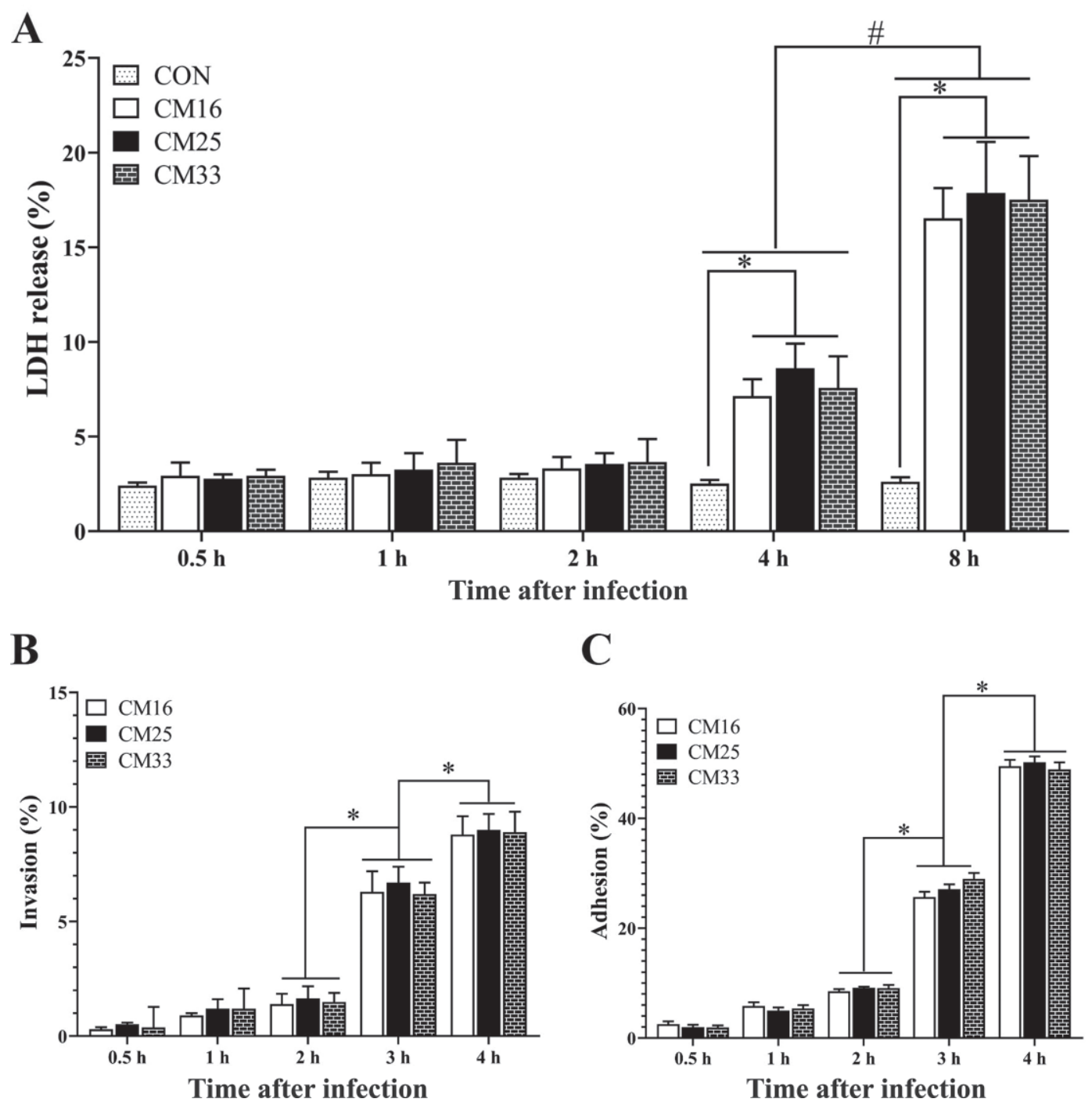

Figure 3. In vitro pathogenic effects of Streptococcus lutetiensis on bovine mammary epithelial cells (bMEC). (A) Effects of Strep. lutetiensis isolates (CM16, CM25, and CM33) on lactate dehydrogenase release of bMEC. Data are mean \pm SD of 3 independent experiments. There was no significant difference among 3 isolates; ${ }^{*}$ indicates a significant difference among control group and treatment groups, and \# indicates a difference between 2 time points $(P<0.05)$. (B) Adhesion to and $(\mathrm{C})$ invasion of Strep. lutetiensis isolates (up to $4 \mathrm{~h}$ after infection) into bMEC. No significant difference among 3 isolates; ${ }^{*}$ indicates a significant difference between 2 time points $(P<0.05)$. 


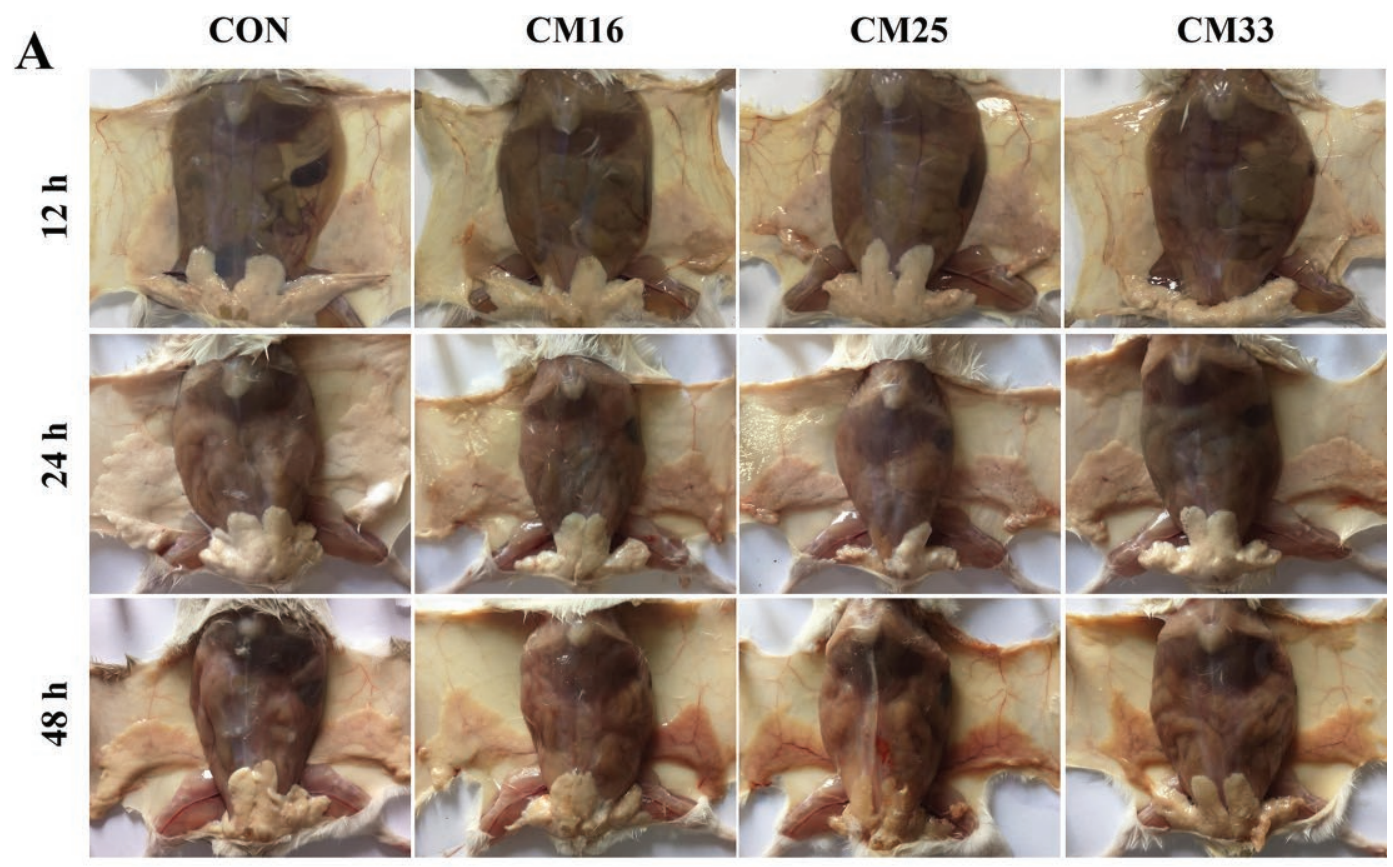

B

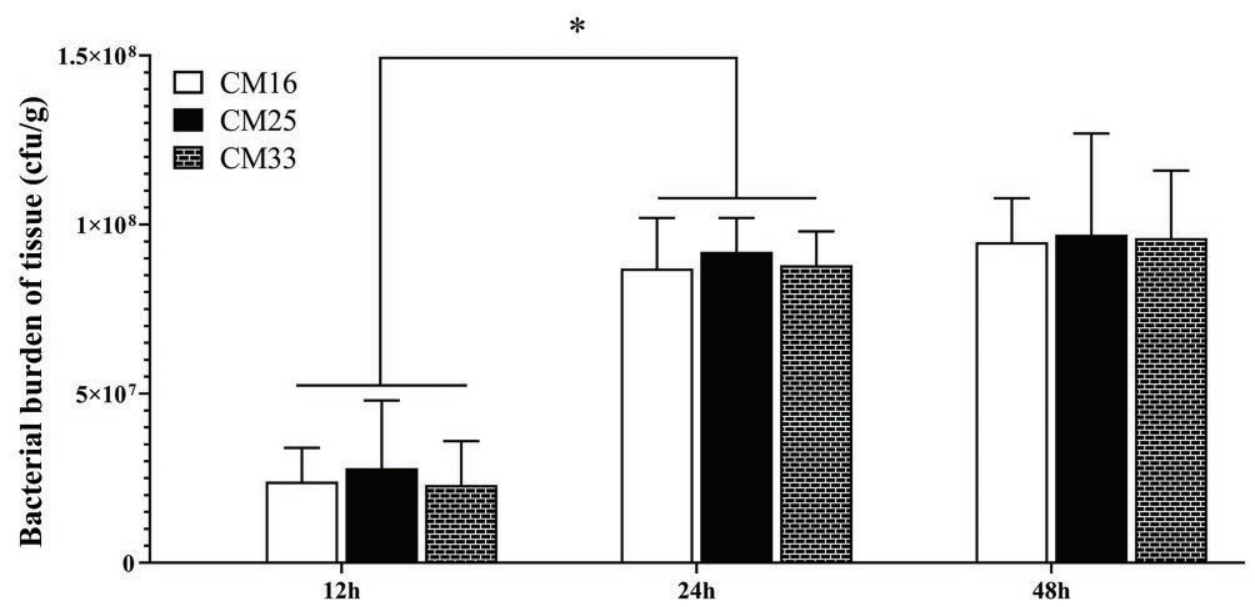

Figure 4. Inflammation of murine mammary gland after intramammary inoculation with Streptococcus lutetiensis. (A) Pathological changes, including edema and hyperemia, in mammary glands of mice challenged with 3 Strep. lutetiensis isolates (CM16, CM25, and CM33). (B) Bacterial burden in mammary glands of mice (up to $48 \mathrm{~h}$ after inoculation). Each time point represents 5 mice in each of the 4 groups. No significant difference among 3 Strep. lutetiensis isolates; $*$ indicates difference $(P<0.05)$. CON $=$ control. Data are mean \pm SD of 3 independent experiments.

isolates from distinct RAPD-types (A, B, and C) were used to reduce the effect of occasionality in experiments. Establishment of an in vitro bMEC infection model is useful to assess virulence of pathogens from mastitic cows (Matthews et al., 1994). In the present study, Strep. lutetiensis rapidly adhered to and invaded bMEC. Assuming that bMEC invasion will occur in vivo, rapid adherence of Strep. lutetiensis may facilitate intracellular invasion, whereas the subsequent invasion into host cells may protect bacteria from antimicrobials, and contribute to development of chronic infections. In addition, the elevated adherence and invasion rates (1-3 h after infection) may accelerate cell damage, reflected by release of much $\mathrm{LDH}$ at $4 \mathrm{~h}$ after infection.

A murine model of intramammary challenge with bovine mastitis pathogens has been successfully used to assess bacterial infection and tissue damage (Pereyra et al., 2017; Liu et al., 2019). In the current study, intramammary infection of Strep. lutetiensis stimulated an inflammatory response in mammary gland of mice, evidenced by gross appearance, massive infiltrations 


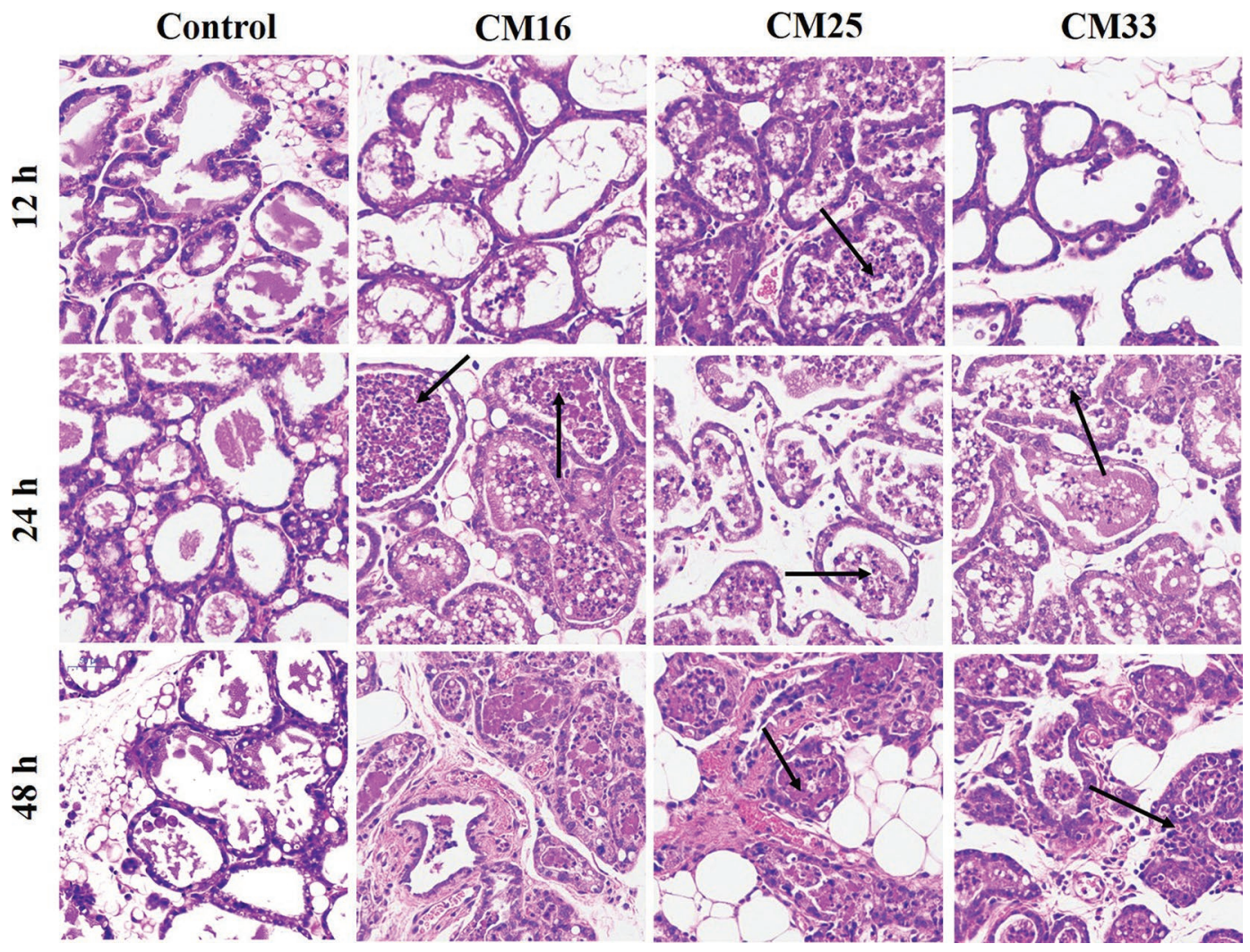

Figure 5. Histological evaluation of mammary tissue (hematoxylin-eosin staining $200 \times$ ). Streptococcus lutetiensis provoked acute mastitis, with an increasing number of inflammatory cells (mainly neutrophils) infiltrated into the gland alveoli and interstitium of the mammary gland (black arrow) after infection.

of inflammatory cells, progressive mammary alveolar damage and bacteria concentration in tissue. Streptococcus lutetiensis increased rapidly and persisted at least $48 \mathrm{~h}$ in murine mammary glands, resulting in the migration of inflammatory cells into mammary tissue, causing edema and hyperemia (Johnzon et al., 2016). In addition to rapid growth and high bacterial counts in vitro, the rapid increase of Strep. lutetiensis in infected mammary gland indicated the organism was well adapted to proliferating in the udder.

\section{CONCLUSIONS}

Streptococcus lutetiensis was isolated in milk samples of mastitic cows on a large Chinese dairy farm. A predominant RAPD-type representing $84 \%$ of isolates indicated Strep. lutetiensis had potential to spread within the herd. In addition, Strep. lutetiensis had adhering and invasive abilities in bMEC and induced cell damage in vitro as well as in an in vivo murine model of intramammary infection. The findings were foundational to elucidate the importance of Strep. lutetiensis as a mastitis pathogen.

\section{ACKNOWLEDGMENTS}

This study was financially supported by Natural Science Foundation of Beijing Municipality (Beijing, China; No. 6192013), the National Natural Science Foundation of China (Beijing; No. 31772813 and 31660730), National Key Research and Development Project (Beijing; 2018YFD0501601-01) and Hebei Key Research and Development Project (Shijiazhuang City; 19226607D). We thank Professor Yang Wang in the College of Veterinary Medicine, China Agricultural University (Beijing), for technical support (InfoQuest FP software) of RAPD data analysis. The authors declare that no competing interest exist.

\section{REFERENCES}

Almuzara, M., L. Bonofiglio, R. Cittadini, C. Vera Ocampo, A. Montilla, M. Del Castillo, M. S. Ramirez, M. Mollerach, and C. Vay. 2013. First case of Streptococcus lutetiensis bacteremia involving a clindamycin-resistant isolate carrying the $\operatorname{lnu\mathrm {B}}$ gene. J. Clin. Microbiol. 51:4259-4261. https://doi.org/10.1128/JCM.01774-13.

Apparao, M. D., P. L. Ruegg, A. Lago, S. Godden, R. Bey, and K. Leslie. 2009. Relationship between in vitro susceptibility test results and treatment outcomes for gram-positive mastitis patho- 
gens following treatment with cephapirin sodium. J. Dairy Sci. 92:2589-2597. https://doi.org/10.3168/jds.2008-1693.

Baron, M. J., G. R. Bolduc, M. B. Goldberg, T. C. Aupérin, and L. C. Madoff. 2004. Alpha C protein of group B Streptococcus binds host cell surface glycosaminoglycan and enters cells by an actindependent mechanism. J. Biol. Chem. 279:24714-24723. https:// doi.org/10.1074/jbc.M402164200.

Beckmann, C., J. D. Waggoner, T. O. Harris, G. S. Tamura, and C. E. Rubens. 2002. Identification of novel adhesins from Group B streptococci by use of phage display reveals that C5a peptidase mediates fibronectin binding. Infect. Immun. 70:2869-2876. https: //doi.org/10.1128/IAI.70.6.2869-2876.2002.

Bi, Y., Y. J. Wang, Y. Qin, R. Guix Vallverdú, J. Maldonado Garcia, W. Sun, S. Li, and Z. Cao. 2016. Prevalence of bovine mastitis pathogens in bulk tank milk in China. PLoS One 11:e0155621. https://doi.org/10.1371/journal.pone.0155621.

Bidet, P., N. Brahimi, C. Chalas, Y. Aujard, and E. Bingen. 2003. Molecular characterization of serotype III group B streptococcus, isolates causing neonatal meningitis. J. Infect. Dis. 188:1132-1137. https://doi.org/10.1086/378517.

Casadevall, A., and L. A. Pirofski. 1999. Host-pathogen interactions: Redefining the basic concepts of virulence and pathogenicity. Infect. Immun. 67:3703-3713. https://doi.org/10.1128/IAI.67.8.3703 $-3713.1999$

Chen, W., Y. Liu, L. Zhang, X. Gu, G. Liu, M. Shahid, J. Gao, T. Ali, and B. Han. 2017. Nocardia cyriacigeogica from bovine mastitis induced in vitro apoptosis of bovine mammary epithelial cells via activation of mitochondrial-caspase pathway. Front. Cell. Infect. Microbiol. 7:194. https://doi.org/10.3389/fcimb.2017.00194.

Cheng, J., W. Qu, H. W. Barkema, D. B. Nobrega, J. Gao, G. Liu, J. De Buck, J. P. Kastelic, H. Sun, and B. Han. 2019. Antimicrobial resistance profiles of 5 common bovine mastitis pathogens in large Chinese dairy herds. J. Dairy Sci. 102:2416-2426. https://doi.org/ $10.3168 /$ jds.2018-15135.

Chongprasertpon, N., R. Cusack, J. J. Coughlan, W. T. Chung, C. H. Leung, and T. J. Kiernan. 2019. Streptococcus bovis endocarditis after colonic polypectomy. Eur. J. Case Rep. Intern. Med. 6:001110. https://doi.org/10.12890/2019_001110.

CLSI (Clinical and Laboratory Standards Institute). 2017. Performance Standards for Antimicrobial Susceptibility Testing. CLSI document M100-S27. CLSI, Wayne, PA.

Coffey, T. J., G. D. Pullinger, R. Urwin, K. A. Jolley, S. M. Wilson, M. C. Maiden, and J. A. Leigh. 2006. First insights into the evolution of Streptococcus uberis: A multilocus sequence typing scheme that enables investigation of its population biology. Appl. Environ. Microbiol. 72:1420-1428. https://doi.org/10.1128/AEM.72.2.1420 -1428.2006 .

Constable, P. D., and D. E. Morin. 2003. Treatment of clinical mastitis: Using antimicrobial susceptibility profiles for treatment decisions. Vet. Clin. North Am. Food Anim. Pract. 19:139-155. https: //doi.org/10.1016/S0749-0720(02)00068-3.

Duarte, R. S., O. P. Miranda, B. C. Bellei, M. A. V. P. Brito, and L. M. Teixeira. 2004. Phenotypic and molecular characteristics of Streptococcus agalactiae isolates recovered from milk of dairy cows in Brazil. J. Clin. Microbiol. 42:4214-4222. https://doi.org/ 10.1128/JCM.42.9.4214-4222.2004.

Facklam, R. 2002. What happened to the streptococci: Overview of taxonomic and nomenclature changes. Clin. Microbiol. Rev. 15:613-630. https://doi.org/https://doi.10.1128/cmr.15.4.613-630 .2002 .

Frank, J. A., C. I. Reich, S. Sharma, J. S. Weisbaum, B. A. Wilson, and G. J. Olsen. 2008. Critical evaluation of two primers commonly used for amplification of bacterial 16S rRNA genes. Appl. Environ. Microbiol. 74:2461-2470. https://doi.org/10.1128/AEM .02272-07.

Friães, A., F. R. Pinto, C. Silva-Costa, M. Ramirez, and J. MeloCristino. 2013. Superantigen gene complement of Streptococcus pyogenes - Relationship with other typing methods and short-term stability. Eur. J. Clin. Microbiol. Infect. Dis. 32:115-125. https:// doi.org/10.1007/s10096-012-1726-3.
Gao, J., H. W. Barkema, L. Zhang, G. Liu, Z. Deng, L. Cai, R. Shan, S. Zhang, J. Zou, J. P. Kastelic, and B. Han. 2017. Incidence of clinical mastitis and distribution of pathogens on large Chinese dairy farms. J. Dairy Sci. 100:4797-4806. https://doi.org/10.3168/ jds.2016-12334.

Garvie, E. I., and A. J. Bramley. 1979. Streptococcus bovis-An approach to its classification and its importance as a cause of bovine mastitis. J. Appl. Bacteriol. 46:557-566. https://doi.org/10.1111/j .1365-2672.1979.tb00855.x.

Halasa, T., K. Huijps, O. Østerås, and H. Hogeveen. 2007. Economic effects of bovine mastitis and mastitis management: A review. Vet. Q. 29:18-31. https://doi.org/10.1080/01652176.2007.9695224.

Hamilton-Miller, J. M. 1991. Calculating MIC50. J. Antimicrob. Chemother. 27:863-864. https://doi.org/10.1093/jac/27.6.863.

Jin, D., C. Chen, L. Li, S. Lu, Z. Li, Z. Zhou, H. Jing, Y. Xu, P. Du, H. Wang, Y. Xiong, H. Zheng, X. Bai, H. Sun, L. Wang, C. Ye, M. Gottschalk, and J. Xu. 2013. Dynamics of fecal microbial communities in children with diarrhea of unknown etiology and genomic analysis of associated Streptococcus lutetiensis. BMC Microbiol. 13:141. https://doi.org/10.1186/1471-2180-13-141.

Johnzon, C. F., K. Artursson, R. Söderlund, B. Guss, E. Rönnberg, and G. Pejler. 2016. Mastitis pathogens with high virulence in a mouse model produce a distinct cytokine profile in vivo. Front. Immunol. 7:368. https://doi.org/10.3389/fimmu.2016.00368.

Khazandi, M., P. Eats, D. Trott, E. Ebrahimie, J. Perry, E. Hickey, S. Page, S. Garg, and K. R. Petrovski. 2015. Development of an improved Streptococcus uberis experimental mastitis challenge model using different doses and strains in lactating dairy cows. J. Dairy Res. 82:470-477. https://doi.org/10.1017/S0022029915000321.

Liu, G., J. Yin, B. Han, H. W. Barkema, M. Shahid, J. De Buck, E. R. Cobo, J. P. Kastelic, and J. Gao. 2019. Adherent/invasive capacities of bovine-associated Aerococcus viridans contribute to pathogenesis of acute mastitis in a murine model. Vet. Microbiol. 230:202-211. https://doi.org/10.1016/j.vetmic.2019.02.016.

Lundberg, A., A. Nyman, H. E. Unnerstad, and K. P. Waller. 2014. Prevalence of bacterial genotypes and outcome of bovine clinical mastitis due to Streptococcus dysgalactiae and Streptococcus uberis. Acta Vet. Scand. 56:80. https://doi.org/10.1186/s13028-014-0080 -0 .

Magiorakos, A. P., A. Srinivasan, R. B. Carey, Y. Carmeli, M. E. Falagas, C. G. Giske, S. Harbarth, J. F. Hindler, G. Kahlmeter, B. Olsson-Liljequist, D. L. Paterson, L. B. Rice, J. Stelling, M. J. Struelens, A. Vatopoulos, J. T. Weber, and D. L. Monnet. 2012. Multidrug-resistant, extensively drug-resistant and pandrug-resistant bacteria: An international expert proposal for interim standard definitions for acquired resistance. Clin. Microbiol. Infect. 18:268-281. https://doi.org/10.1111/j.1469-0691.2011.03570.x.

Manning, S. D., M. Ki, C. F. Marrs, K. J. Kugeler, S. M. Borchardt, C. J. Baker, and B. Foxman. 2006. The frequency of genes encoding three putative group B streptococcal virulence factors among invasive and colonizing isolates. BMC Infect. Dis. 6:116. https:// doi.org/10.1186/1471-2334-6-116.

Matsumoto, M., N. P. Hoe, M. Liu, S. B. Beres, G. L. Sylva, C. M. Brandt, G. Haase, and J. M. Musser. 2003. Intrahost sequence variation in the streptococcal inhibitor of complement gene in patients with human pharyngitis. J. Infect. Dis. 187:604-612. https:/ /doi.org/10.1086/367993.

Matthews, K. R., J. J. Rejman, J. D. Turner, and S. P. Oliver. 1994. Proliferation of a bovine mammary epithelial cell line in the presence of bacterial virulence factors. J. Dairy Sci. 77:2959-2964. https://doi.org/10.3168/jds.S0022-0302(94)77237-4.

Noble, C. J. 1978. Carriage of group D streptococci in the human bowel. J. Clin. Pathol. 31:1182-1186. https://doi.org/10.1136/jcp .31.12.1182.

Pereyra, E. A. L., S. C. Sacco, A. Duré, C. Baravalle, M. S. Renna, C. S. Andreotti, S. Monecke, L. F. Calvinho, and B. E. Dallard. 2017. Immune response of Staphylococcus aureus strains in a mouse mastitis model is linked to adaptive capacity and genotypic profiles. Vet. Microbiol. 204:64-76. https://doi.org/10.1016/j.vetmic .2017.04.009. 
Petrovski, K. R., M. Trajcev, and G. Buneski. 2006. A review of the factors affecting the costs of bovine mastitis. J. S. Afr. Vet. Assoc. 77:52-60. https://doi.org/10.4102/jsava.v77i2.344.

Pinzón-Sánchez, C., and P. L. Ruegg. 2011. Risk factors associated with short-term post-treatment outcomes of clinical mastitis. J. Dairy Sci. 94:3397-3410. https://doi.org/10.3168/jds.2010-3925.

Piva, S., M. Pietra, A. Serraino, G. Merialdi, J. Magarotto, and F. Giacometti. 2019. First description of Streptococcus lutetiensis from a diseased cat. Lett. Appl. Microbiol. 69:96-99. https://doi.org/10 .1111/lam.13168.

Poyart, C., G. Quesne, and P. Trieu-Cuot. 2002. Taxonomic dissection of the Streptococcus bovis group by analysis of manganese-dependent superoxide dismutase gene $(\operatorname{sod} A)$ sequences: Reclassification of 'Streptococcus infantarius ssp. coli' as Streptococcus lutetiensis sp. nov. and of Streptococcus bovis biotype 11.2 as Streptococcus pasteurianus sp. nov. Int. J. Syst. Evol. Microbiol. 52:1247-1255. https://doi.org/10.1099/00207713-52-4-1247.

Proft, T., and J. D. Fraser. 2016. Streptococcal superantigens: Biological properties and potential role in disease. Pages 445-486 in Streptococcus pyogenes: Basic Biology to Clinical Manifestations. J. J. Ferretti, D. L. Stevens, and V. A. Fischetti, ed. University of Oklahoma Health Sciences Center, Oklahoma City, OK.

Pyörälä, S. 2009. Treatment of mastitis during lactation. Ir. Vet. J. 62(Suppl. 4):S40-S44. https://doi.org/10.1186/2046-0481-62-S4 $-\mathrm{S} 40$.

Qu, Y., H. Zhao, D. B. Nobrega, E. R. Cobo, B. Han, Z. Zhao, S. Li, M. Li, H. W. Barkema, and J. Gao. 2019. Molecular epidemiology and distribution of antimicrobial resistance genes of Staphylococcus species isolated from Chinese dairy cows with clinical mastitis. J. Dairy Sci. 102:1571-1583. https://doi.org/10.3168/jds.2018-15136.

Rato, M. G., A. Nerlich, R. Bergmann, R. Bexiga, S. F. Nunes, C. L. Vilela, I. Santos-Sanches, and G. S. Chhatwal. 2011. Virulence gene pool detected in bovine group C Streptococcus dysgalactiae ssp. dysgalactiae isolates by use of a group A S. pyogenes virulence microarray. J. Clin. Microbiol. 49:2470-2479. https://doi.org/10 .1128/JCM.00008-11.

Ruegg, P. L. 2017. A 100-year review: Mastitis detection, management, and prevention. J. Dairy Sci. 100:10381-10397. https://doi .org/10.3168/jds.2017-13023.
Schlegel, L., F. Grimont, E. Ageron, P. A. D. Grimont, and A. Bouvet. 2003. Reappraisal of the taxonomy of the Streptococcus bovis/ Streptococcus equinus complex and related species: Description of Streptococcus gallolyticus subsp. gallolyticus subsp. nov., S. gallolyticus subsp. macedonicus subsp. nov. and S. gallolyticus subsp. pasteurianus subsp. nov. Int. J. Syst. Evol. Microbiol. 53:631-645. https://doi.org/10.1099/ijs.0.02361-0.

Tripodi, M. F., R. Fortunato, R. Utili, M. Triassi, and R. Zarrilli. 2005. Molecular epidemiology of Streptococcus bovis causing endocarditis and bacteraemia in Italian patients. Clin. Microbiol. Infect. 11:814-819. https://doi.org/10.1111/j.1469-0691.2005.01248 .x.

Verbeke, J., S. Piepers, K. Supré, and S. De Vliegher. 2014. Pathogenspecific incidence rate of clinical mastitis in Flemish dairy herds, severity, and association with herd hygiene. J. Dairy Sci. 97:69266934. https://doi.org/10.3168/jds.2014-8173.

Wente, N., D. Klocke, J. H. Paduch, Y. Zhang, M. T. Seeth, V. ZocheGolob, F. Reinecke, E. Mohr, and V. Krömker. 2019. Associations between Streptococcus uberis strains from the animal environment and clinical bovine mastitis cases. J. Dairy Sci. 102:9360-9369. https://doi.org/10.3168/jds.2019-16669.

WHO (World Health Organization). 2015. Global action plan on antimicrobial resistance. Accessed Sep. 14, 2018. http://www.who.int/ drugresistance/global_action_plan/en/.

Zhang, S., S. Piepers, R. Shan, L. Cai, S. Mao, J. Zou, T. Ali, S. De Vliegher, and B. Han. 2018. Phenotypic and genotypic characterization of antimicrobial resistance profiles in Streptococcus dysgalactiae isolated from bovine clinical mastitis in 5 provinces of China. J. Dairy Sci. 101:3344-3355. https://doi.org/10.3168/ jds.2017-14031.

\section{ORCIDS}

Weijie Qu (® https://orcid.org/0000-0001-8984-7205

John P. Kastelic @ https://orcid.org/0000-0003-4607-3355

Bo Han (ㅇ https://orcid.org/0000-0002-4798-7725

Jian Gao @ https://orcid.org/0000-0001-5059-2698 